\title{
Sexual abuse in childhood and the unconscious repetition of pain in couple relationships
}

Sexual abuse is a traumatic experience that marks the victim in a variety of areas. This article will focus on the sexually abused and who attracts them to fall in love. A description of the partnership dynamics, in which one or both partners experienced sexual abuse as a child, will follow. We will focus on how those with a history of sexual abuse now experience sexuality, as it was their bodies that were the most exposed to the experience of the traumatic event(s). Despite the consequences, which may arise directly or after several years, the author addresses the element of hope and new beginnings at the end of the article. She speaks about how the couple relationship has the potential

* Tanja Repič Slavič is a doctor of sciences (a PhD degree in 2008) as well as a marriage and family therapist. She is a researcher and associate professor at the Faculty of Theology, University in Ljubljana, Slovenia, at the Chair of Marriage and Family Therapy, Department of Marriage and Family Therapy, Psychology and Sociology of Religion, where she works as a lecturer in the marriage and family studies master's program and the advanced studies/ doctoral program of marriage and family therapy. She actively participates in international conferences at home and abroad. Her scientific and research papers on traumas, especially sexual and physical abuse, partner relationships and parenthood, have been published in Slovenia and abroad. She takes part in Slovenian and international scientific symposia and conferences on various topics addressing traumas, especially in relation to marriage and family. 
for healing traumatic memories if both partners allow and accept the choice for the change and thus bring an end to the vicious and repetitive cycle of pain.

"I don't remember when it first started. I do remember that it was expected and normal in our home that I slept between daddy and mommy, and not just as a small child, but onwards through puberty... I would lie there between them, and night after night my dad would stroke and touch my whole body, and in return I had to massage and rub him as long as it took for him to finally wet me. That's how he got me used to this touching. He convinced me that it's how it is and what it means to be loved. And I couldn't relax and fall asleep anymore if I didn't first crawl over to his part of the bed, where it all happened, over and over again. And where was my mother? She was pretending to be asleep. I can remember from early on how I felt, deep down, that something is not right. Every morning I was ashamed to look my own mommy in the eyes. It felt like I was stealing daddy from her, not to mention the guilt! And yet it was the 'strongest goodnight lullaby' I had... I remember how my daddy gave me a special ' $g i f f$ ' for $m y 9^{\text {th }}$ birthday, because he loved me so much. Mommy was working the night shift, so she was away. He lay on top of me and penetrated my small, child's body... If someone had told me then that my dad is bad and hurtful, I would not have believed them. Today, after so many tears, suffering, sleepless nights and broken relationships, I now know that these were not innocent goodnight games, but actually the most atrocious acts of criminal abuse. And they will never be punished enough!"

\section{Trauma of sexual abuse}

Sexual abuse is a traumatic experience that profoundly marks the victim in a variety of areas: as regards self-esteem, sexuality, physicality, and especially partnership relations. ${ }^{1}$ It also destroys the internal boundaries of the abused, whereby boundaries are what enable us to gauge how close we let someone get to us and to whom we say how much and why. Internal boundaries also

1 Cf. B. Corby, Child abuse towards a knowledge base, Maidenhead 2006; J. L. Davis, P. A. Petretic-Jackson, The impact of child sexual abuse on adult interpersonal functioning: a review and synthesis of the empirical literature, "Aggression and Violent Behavior" 2000 No. 5, pp. 291-328; S. Knauer, Recovering from sexual abuse, addictions, and compulsive behaviors: "numb" survivors, New York 2002. 
help us recognize who is feeling which emotion, where it is coming from, as well as where and for whom it is intended. ${ }^{2}$ People without healthy internal boundaries will always feel obliged to help others, to do something more, or rather to continually allow themselves to be exploited; they will explain overly intimate things to others and tend to give more information than necessary. What protects people from being abused again are internal boundaries and fear, which are sometimes consumed by abuse. Fear can become so deeply repressed that a victim may not recognize it. Consequently, he/she will often unwittingly find themselves in new situations where the atmosphere of abuse is repeated. ${ }^{3}$ Research shows that adults who were sexually abused as children often sexualize relationships, and that sex is a medium through which they show affection; or, conversely, that it is through sex that someone else will show their affection and love for them. ${ }^{4}$ This little girl, accustomed since early childhood that her father demonstrated his "love" and "affection" for her in an, albeit very inappropriate way (sexual abuse), nonetheless built the strongest commitment and relationship with her father on the very basis of his abuse. Of course she felt most deeply connected with her father, despite it being in an extremely negative way, whenever he stroked and touched her. The abuse or more precisely, the effects of disgust, contempt and shame - was imprinted not only in her psyche, but also in all the fibers of her body and the chemicalhormonal system. ${ }^{5}$ She will then seek new relationships in adulthood on the basis of these affects, which will make her feel secure, familiar, and natural on an unconscious level. In other words, even if she consciously yearns for a healthy sense of love, belonging and respect, unconsciously she will not be attracted to these affects, as they will not feel safe. The problem is that she lacks abuse and intensity that remind her of the primary relationship with her

2 Cf. P. Fonagy, G. Gergely, E. L. Jurist, M. Target, Affect regulation, mentalization, and the development of the self, New York 2007; C. Gostečnik, Relacijska paradigma in travma, Ljubljana 2009, Inovativna relacijska družinska terapija, Ljubljana 2011, Relacijska paradigma in klinična praksa, Ljubljana 2013.

3 Cf. R. Cvetek, Bolečina preteklosti: Travma, medosebni odnosi, družina, terapija, Celje 2010; C. Gostečnik, Relacijska paradigma in travma...

4 Cf. J. L. Davis, P. A. Petretic-Jackson, The impact of child sexual abuse..., pp. 291-328.

5 Cf. P. Fonagy, G. Gergely, E. L. Jurist, M. Target, Affect regulation...; J. B. Kaplow, C. S. Widom, Age of onset of child maltreatment predicts long-term mental health outcomes, "Journal of Abnormal Psychology" 2007 No. 116 (1), pp. 176-187; B. Rothschild, The body remembers: the psychophysiology of trauma and trauma treatment, New York 2000. 
abusive father. ${ }^{6}$ These repeated feelings of abuse are so strong and binding that only they can calm the body; they become the "daily bread," without which the abused child can barely live. The cruelty lies in how it's almost as if an abused child's body will seek out her father before going to bed so as to "ask" to receive that "calming" effect, that is, to be nailed with disgust, shame and contempt. Most abusers will interpret a child's distress as the child's own fault and that the child asked for it and even crawled into their lap for it. The child, however, is never at fault. It is always the adult who carries the weight of responsibility and accountability for the act of abuse.

This search for connection, or rather allegiance and loyalty to the abuser, is an excellent illustration of Fairbairn's research ${ }^{7}$, in which he identified and established how abused children are loyal to their parents, regardless of how they were abused by them. Abused children were taken from these abusive parents and relocated with foster parents, who were especially nurturing, kind and loving; but the children acted out and "went crazy" with them, they rejected their foster parents. They calmed down only once they were returned to their biological (albeit abusive) parents. This was proof of the strong tendency and extremely unconditional attachment to their own (abusive) parents, or rather to the atmosphere and the affect that they experienced with them, because these carried the promise of a sense of security, belonging and relationship.

Children do not naturally want sex with their parents; but if they are exposed to it from early on, and experience that it delivers the most attention, affection and connection, they will be willing to do everything simply to maintain this sense of connection. Deep down they will feel that something is not right. They will carry the guilt, shame and disgust, even though these feelings are those of the perpetrators, but the perpetrators are not connected with them, not in touch with them (otherwise they would not sexually abuse), and so they unconsciously project them upon their victims. Most likely the perpetrators had similar experiences themselves, however this does not release them of their responsibility for the offense. Clinical experience suggests that the guilt, shame and disgust are even more severe when adult

6 Cf. C. Gostečnik, Relacijska paradigma in klinična praksa...; M. F. Solomon, D. J. Siegel, Healing trauma: attachment, mind, body, and brain, New York 2003.

7 Cf. W. R. D. Fairbairn, An object relations theory of the personality, New York 1952. 
women (who had been sexually abused in childhood) remember that they even experienced orgasm during the abuse. It is no less a criminal act in such cases, and the perpetrator remains fully responsible for the abuse. The body of the victim merely demonstrated that it was healthy and functional, and so it responded to the physical stimuli with orgasm. ${ }^{8}$ Another response of the body may be to "freeze over," which means that the abused child does not feel their body simply because they had to block it out. Those who were sexually abused often describe such moments as having the sensation of hovering over their body, as having bound and tingling legs, as feeling that they are not in their body and only looking on from afar at what was happening. The feelings that flood the body are too intense, so the psyche protects itself by splitting off, by dissociating. But the body remembers all of it. ${ }^{9}$ Everything that this little child, this little girl, had to suppress and could not afford to feel as a child, or else she would not survive it, will come up and out later, often in the cruelest of forms (such as nightmares, sleep disturbances, depression, addictions, broken relationships, violence and conflicts, etc.). In situations that are unconsciously reminiscent of the original abuse, the adult "little girl" - now a woman - will feel all the stifling fear, disgust, contempt, shame and guilt. She will begin to feel everything that she was unable to as a child, everything that was too dangerous for her survival. At the same time, she will even think she is crazy, that there is something terribly wrong with her, that it is all her fault; she will fail to connect these feelings with the actual abuse, which evidently re-awakened because it was safe enough for her psyche. This little girl will feel guilty for everything, even crazy: it was suffocating, and hard to fall asleep, she was caught between her father and mother, but could not feel any of it, or else she might die of fear. Unconsciously, she safely suppressed it all, perhaps even deleted images and memories of the event itself; but her body remembers everything. Imprinted in her body is all the distress, disgust, shame, fear, guilt, the perpetrator's behavior, even postures, sensorial experiences, some sentence that the perpetrator might have spoken during, before or after the abuse. ${ }^{10}$ And it is difficult in therapy to predict when the memory and images will be re-triggered. Clinical experience shows that each

8 Cf. E. Bass, L. Davis, Pogum za okrevanje, Ljubljana 1998.

9 Cf. B. Rothschild, The body remembers...

10 Cf. T. Repič, Nemi kriki spolne zlorabe in novo upanje, Celje 2008. 
individual has their own process for seeking resolution and purification (of the body and psyche) from the abuse, and also that the more conscious links there are connecting the original abuse with current events, the easier it is for the abused victim to move on through life.

\section{Falling in love and having a history of sexual abuse}

The tragedy here is that the chance to resolve the trauma of sexual abuse among those who were sexually abused lies in their falling in love and becoming involved in a relationship where, sooner or later, all the affects from the original abuse crop up and repeat themselves with full vehemence. A sexually abused woman will consciously seek out a man who will seem entirely different from all those rude, obscene, and corrupt men who once abused her. She will seek out a man who will seem friendly, understanding, respectful, someone who hears and feels her pain. However, these men will not be attractive to her at an unconscious level, the level that so strongly influences the selection of a partner. The one who will be attractive to her will have similar affects (shame, disgust, contempt, fear, etc.) in his internal psychic structure, and he will be wounded and traumatized much the same as she was. ${ }^{11}$ This does not mean that he was also sexually abused as a child; rather, perhaps he simply grew up in a family atmosphere imbued with anxiety, violence, no emotional boundaries between the father and the mother, possible infidelity on the part of the parents, or maybe even the parents presented the appearance of functioning well together, but the child was a victim to their unresolved intrapsychic content and conflicts from childhood. In other words, the parents might have suffered sexual or other abuse in their own childhood, and the traces of shame, disgust, fear, and similar terror remained unresolved. Perhaps the unconscious simply managed through denial, dissociation and suppression. And then follows a quick marriage, a new child, and suddenly this new child is nursing in the mother's arms and soaking up all these unresolved feelings that have become part of her internal psychic structure. This is referred to as a transgenerational transfer of emotions when the consequences of a particular trauma pass

11 Cf. C. Gostečnik, Relacijska paradigma in klinična praksa... 
on to the next generation, even to children not yet born at the time of the traumatic event. ${ }^{12}$ However, the research on the transmission of emotions between generations differs. Some authors ${ }^{13}$ estimate that approximately one third of sexually abused individuals continue the abuse, and about two thirds of the victims will never themselves sexually abuse, especially if they have the support and love of family. Johnson ${ }^{14}$ found that those who were once victims of emotional, physical or sexual abuse are six times more likely to continue abusing or continue experiencing the abuse they know so well. Other studies ${ }^{15}$ show that half of mothers whose children experience sexual abuse were sexually abused themselves.

So, the sexually abused woman is predisposed to falling in love with a similarly wounded and traumatized man. She will consciously be trying to run from shame and disgust and intense traumatic experiences, while unconsciously she will be liable to seek out an emotional atmosphere reminiscent of home (abuse), as only this atmosphere gives a feeling of security and belonging. Deeply wounded individuals normally attract each other very quickly, upon which they fall "crazy" in love. This love can seem excessive to the outside world, destructive or even abnormal, but the two in love often feel they have always known each other and were surely meant for each other. Falling in love activates all the chemistry in us, our entire biological and hormonal systems, leaving our bodies trembling with longing for a safe embrace, and for the love and acceptance of our nearest and dearest. ${ }^{16}$

Some research suggests that sexually abused people change partners more frequently and start having sex sooner than those who were never sexually

12 Cf. D. R. Catherall, Handbook of stress, trauma and the family, New York 2004.

13 Cf. J. Kaufman, E. Zigler, Do abused children become abusive parents?, "American Journal of Orthopsychiatry" 1987 No. 57, pp. 186-191; R. K. Hanson, S. Slater, Sexual victimization in the history of sexual abusers: A review, "Annals of Sex Research" 1988 No. 1, pp. 485-499.

14 Cf. C. T. Johnson, Some considerations about sexual abuse and children with sexual behavior problems, in: Trauma and sexuality the effects of childhood sexual, physical, and emotional abuse on sexual identity and behavior, eds. J. Chu, E. S. Bowman, New York 2002.

15 Cf. D. Collin-Vezina, Current understanding about intergenerational transmission of child sexual abuse, "Child Abuse \& Neglect" 2003 No. 27 (5), pp. 489-508.

16 Cf. T. Repič, Spolna zloraba in proces relacijske družinske terapije [unpublished doctoral dissertation, the Faculty of Theology, the University of Ljubljana], Ljubljana 2007. 
abused. ${ }^{17}$ They are looking for a relationship by way of the body and sexuality. On the other hand, sexually abused individuals may choose to totally reject any relationship, viewing them only as new abuse. These individuals can become emotionally and biologically completely shut down, inaccessible, and incapable of any close connection. They reject closeness, are unconsciously afraid of relationships and cannot fall in love as their bio-chemical-hormonal system is also blocked. ${ }^{18}$

\section{When the falling in love part is over, the reality of the couple relationship remains for the sexually abused}

What commonly follows when the novelty of falling in love wears off, which usually happens very quickly, is a true vicious circle of comings and goings, conflicts, violence, blame, shame, humiliation and guilt, all of which are the result of unprocessed experiences of sexual abuse emerging. This kind of relationship, full of pain and distress, can continue even several years, despite that the partners have repeatedly "ended" the relationship, this time for good, only to find that after a few days, even hours, follows an insatiable yearning and missing. They panic and feel their only chance at survival is to get back together again, so they give each other one "last" chance. They feel they cannot live with each other, or without. It is truly a hormonal addiction when the body can no longer calm itself without that embrace and atmosphere, which unconsciously reminisces of abuse. These are relationships where the partners "love, because they need each other" and not vice versa, that they "need each other, because they love each other." What happens in these situations is that a little abused child is roused in the grown individual, one who was too often shamed, blamed, humiliated and abused, and who now unconsciously seeks a sense of belonging and security with a partner who also humiliates, shames, blames. Or with a partner who then gets shamed, blamed, and humiliated. This kind of shame can manifest as provocative dressing, or dressing in old and stretched clothes, in neglect, or in shabbiness. Or it can be displayed

17 Cf. M. Cohen, C. Deamant, S. Barkan, et al., Domestic violence and childhood sexual abuse in HIV-infected women and women at risk for HIV "American Journal of Public Health" 2000 No. 90 , pp. 560-565.

18 Cf. C. Gostečnik, Relacijska zakonska terapija, Ljubljana 2015. 
through obscene speech. Most of all it is in our internal posture. Such people usually do not feel shame, simply because they are not connected with or attuned to it; but everyone around them will feel their shame. Humiliation can be seen in the pleading or "begging" for what you are entitled to, in the criticism and harsh words that offend and hurt. Neither the one who humiliates nor the one who is a victim to humiliation has boundaries. These roles of the "tormentor and victim" may alternate; that is, both partners humiliate and shame each other. Guilt is triggered daily, constantly reminding the individual how they have yet again arrived somewhere at the wrong time and the wrong place and that everything they do is wrong. This gives cause to not believe in or listen to one's own intuition, even though it is our sole infallible compass. The repeated and unconscious reawakening of emotions evocative of abuse serves to regulate intimacy between partners. Despite that both partners consciously want and try to succeed at creating and cultivating a comfortable and enjoyable atmosphere while together, their joint unconscious world is so very dangerous that they connect through conflict, thus increasing the emotional distance between themselves, digging their heels in at a safe distance from each other. All until they begin to feel the distress of missing each other, at which point they start pulling closer to each other again. This is the vicious circle within with such a couple whirls round and round, repeatedly acting out their dynamic of coming closer and withdrawing. ${ }^{19}$

\section{Sexual abuse and experiencing sex}

Often the fears of rejection, loneliness and the abandonment of a partner are so strong that the fastest way for the body to attain calm after serious disputes is through a sexual intercourse. We might even say that partners use (and abuse) each other's bodies in order to reconnect. After all, this is how the little girl felt most connected and close to her father: while he was abusing her child's body. Today, she will feel similar sensations to those she felt, or rather suppressed, when her father "completed" the abuse - guilt, disgust and contempt - also with her partner after a sexual intercourse. The feelings of

19 Cf. T. Repič, Spolna zloraba... 
discomfort, guilt, and disgust with herself for "giving in" again will overwhelm her, or her partner will disgust her when he makes some movement, a gesture, which will unconsciously reminisce of the abuse. It is so utterly unjust that the childhood abuse deprives her of so much, including her own capacity to relax and take pleasure in having sex with her partner. And the same holds true vice versa, as even her partner with a similar history (they would not otherwise be mutually attracted to each other) is deprived of similar feelings. Some studies ${ }^{20}$ suggest that sexually abused women experience many more negative feelings (e.g. fear, contempt and disgust) during sexual arousal than those who were not abused. These feelings are largely predecessors of sexual dysfunction and sexual dissatisfaction. Also, there is a positive correlation between women with a history of sexual abuse and those with a large repertoire of sexual fantasies, liberal sexual attitudes, masturbation and a higher frequency of sexual relations with various partners. In general, experiencing sex among the sexually abused can be categorized into three responses, or behaviors. ${ }^{21}$ Although, how any given individual will react, or which behavior they will manifest, cannot be predicted.

1. The first reaction is aversion or a resistance to, and avoidance of sex. Here the sexually abused person responds to touch, especially touching reminiscent of the abuse, by freezing over; they will not feel their body or be able to relax and take pleasure in sex. This individual will feel much more anxiety and unpleasant feelings with regard to sex, a constant sense of guilt; at the same time, they will do everything to avoid even the thought of sex, let alone sex in itself. These people often cultivate an inner attitude, a perspective, that sex is dirty, shameful and guilt-inspiring.

2. The second reaction is an obsession or preoccupation with sex. Sex becomes the only "cure;" the one that best calms the body and delivers the most powerful sense of connection and belonging in a relationship. For these people, "to love" will mean and manifest through sexual closeness,

20 Cf. W. Maltz, B. Holman, Incest and sexuality: a guide to understanding and healing, San Francisco 1987; C. Courtois, Healing the incest wound: adult survivors in therapy, New York 1988.

21 Cf. A. A. Hughes, R. A. Bean, J. M. Harper, Sexual abuse and subsequent risky sexual behaviors: a competency model for treatment of adolescent females, "The American Journal of Family Therapy” 2015 No. 43 (4), pp. 326-338; C. M. Meston, J. R. Heiman, The relation between early abuse and adult sexuality, "Journal of Sex Research" 1999 No. 36 (4), pp. 385395; T. Repič, Nemi kriki spolne... 
to surrender in the bodily sense. For these people, to be rejected in this sense - be it that the partner will not want to have sexual intercourse or even just give a hug - will awaken the feeling being unloved, rejected or even abandoned. This preoccupation with sex is indicative of unexpressed and deeply internalized sexual compulsions, which may also manifest in various forms: excessive masturbation and viewing of pornographic images and using other sexual devices that prey on sexual fantasies, indulgence in extreme sexual games, early sexual intercourse, etc. Unexpressed and internalized sexual compulsions can also manifest through other obsessive-compulsive behaviors (e.g. spending money recklessly, overindulgence of food, bulimia, anorexia nervosa, gambling, etc.), phobias and anxiety disorders.

3. Ambivalence refers to the simultaneous experiencing of resistance and obsession with sex. As much as this person will want and yearn for tenderness and sex, they will also experience true disgust and repulsion. This very disgust will paradoxically somehow arouse and attract them. "Flashback" images will often occur during sexual intercourse, images of the actual abuse, the image of the partner will be exchanged with that of the perpetrator right in front of their eyes. Sometimes the urge and desire for violence and torture arises in these victims, to permeate the atmosphere with abuse. They likely may not even recognize or be aware of the original abuse reawakening; this is simply because the desire for arousal and orgasm is a stronger feeling. But they will, once sexual intercourse is concluded, and once the body calms, feel the agony of severe guilt, disgust and contempt. If the perpetrator was the father, the sexual ambivalence will be significantly higher. If the perpetrator of the abuse did not use physical force, the victims tend to experience more feelings of guilt and self-accusation; this of course greatly influences the experience of confusion during arousal and the ultimate developmental course of sexual ambivalence.

Research and clinical experience show that in addition to problems with sexuality, sexually abused persons encounter frequent problems in their couple relationships, especially as concerns trusting their partner, due to acute fear that their partner will abandon them or be unfaithful. Or vice versa, the partner may not trust the abused person, who will be experienced as unpredictable and unsafe, the result being that the couple will tend to overly control each other. The urge to control will not be out of concern so much as from the internal distress that rages from within and prevents the 
partners from relaxing and trusting each other. Furthermore, the couple will even unconsciously do everything to regenerate this terror. This type of distrust has roots reaching in the past to when the child was abused by the very person who she most trusted. All the fear and the feeling that it is not safe has its origins in the abuse: indeed the child accurately felt afraid, but she had to suppress it to convince herself that she is safe, otherwise the feelings of fear would become unmanageable and too threatening to survival.

\section{Conclusion}

The severely painful and traumatic feelings and affects are not only more binding, commanding unconditional loyalty, but they also provide the strongest building material for the psyche itself. Abused individuals will seek out similar circumstances and people with whom the abusive affects can be reinstated, each time with the renewed hope of finding resolution to the abusive affect. ${ }^{22}$ From this perspective, two partners can, on the one hand present each other with the most harmful and degenerate ordeal (if they only repeat old patterns), while on the other hand they may together engender the only course to salvation (by risking doing something new).

Compromises, advice, negotiations and tending to the desires and needs of the partner is not enough. To begin, many painstaking and sincere discussions will be necessary, where instead of shaming, attacking, defending, humiliating, insulting and criticizing each other, partners give each other opportunity to express their pain, their distress, and their needs, without having to sacrifice their dignity. Sometimes it's enough just to remain silent out of respect for the vulnerability of those who took a chance to express their fears, doubts, horror and sorrow; and sometimes words can be calming, but only if they are empathic.

Empathy is one of the riskiest things in such deeply wounded partners. When a man allows himself to feel a woman (or vice versa) in her distress and pain, he risks, in the process of reflection, happening upon and feeling his own horrifying pain. This is a pain so deep that he has always managed

22 Cf. C. Gostečnik, Relacijska paradigma in travma...; T. Repič, Nemi kriki spolne... 
to suppress it so far - either by way of violence, shaming, humiliation or by withdrawing into his own world, work or various addictions.

To feel one's own pain requires that the individual reaches deep, back to that world of being a little girl or boy, where the only way for the child to survive was to suppress every trace of abuse. However, this does not mean that the abuse was thus eradicated, as if "what we do not know cannot hurt." In fact, what we do not know can hurt even more, and it has even more power because it works in the unconscious world, over which we have no control. All until we bring it to a conscious level of awareness.

If the traumatized man and woman put in the effort and provide each other an opportunity to hear each other, and allow themselves to enter into their co-created emotional space, this relationship will be something novel for the relevant psyche, something that will begin to heal and resolve the wounds from abuse. This does not mean that there will no longer be conflicts, but it does mean that they can begin to cultivate dignity and respect in new and positive ways that are conducive to the resolution of their plight. With this new internal stance they will be able to begin trusting their intuition again.

This kind of emotional atmosphere will be more conducive to the couple being able to recognize and know each other, and to realize how abusive emotions are being triggered between them, ones they were unable to feel before because they were too intense and threatening to the extreme. In fact, they are "only emotions," and they are manageable today for the grown woman and man, despite them not seeming so - which is because the inner child, the one who no one ever heard when she or he called for help, was reawakened. "If a little boy or a little girl could survive all the horror when the abuse was happening, then they are all the more capable of surviving and thriving as a grown man or woman when it is just a matter of the abuse reawakening."

The new atmosphere and the new experiences will help the bodies of each partner begin to feel truly embraced and loved, and they will have a new capacity to recognize an abusive touch. They will begin to set boundaries, which previously did not exist. Fear, shame, and anger, which provide security and protect the individual from relationships and circumstances where abuse can be repeated, will be revived. This is the stage at which two partners who love each other can choose to commit, and then begin to create their own history. Until now, the abuse was the main facilitator in the relationship, and the partners only re-lived the pasts of the little boy and girl; it was so strong 
that it was their present. In cases where the risk of generating something new is still too dangerous and painful, where there is too much suffering transpiring in the relationship, it will be necessary to also seek professional help.

\section{Bibliography}

Bass E., Davis L., The courage to heal: a guide for women survivors of child sexual abuse, Bloomington 1998.

Catherall D. R., Handbook of stress, trauma and the family, New York 2004.

Cohen M., Deamant C., Barkan S., et al., Domestic violence and childhood sexual abuse in HIV-infected women and women at risk for HIV, "American Journal of Public Health" 2000 No. 90, pp. 560-565.

Collin-Vezina D., Current understanding about intergenerational transmission of child sexual abuse, "Child Abuse \& Neglect" 2003 No. 27 (5), pp. 489-508.

Corby B., Child abuse towards a knowledge base, Maidenhead 2006.

Courtois C., Healing the incest wound: Adult survivors in therapy, New York 1998.

Cvetek R., Bolečina preteklosti: travma, medosebni odnosi, družina, terapija, Celje 2010.

Davis J. L., Petretic-Jackson P. A., The impact of child sexual abuse on adult interpersonal functioning: A review and synthesis of the empirical literature, "Aggression and Violent Behavior" 2000 No. 5, pp. 291-328.

Fairbairn W. R. D., An object relations theory of the personality, New York 1952.

Fonagy P., Gergely G., Jurist E. L., Target M., Affect regulation, mentalization, and the development of the self, New York 2007.

Gostečnik C., Relacijska paradigma in travma, Ljubljana 2009.

Gostečnik C., Inovativna relacijska družinska terapija, Ljubljana 2011.

Gostečnik C., Relacijska paradigma in klinična praksa, Ljubljana 2013.

Gostečnik C., Relacijska zakonska terapija, Ljubljana 2015.

Hanson R. K., Slater S., Sexual victimization in the history of sexual abusers: a review, "Annals of Sex Research" 1988 No. 1, pp. 485-499.

Hughes A. A., Bean R. A., Harper J. M., Sexual abuse and subsequent risky sexual behaviors: a competency model for treatment of adolescent females, "The American Journal of Family Therapy" 2015 No. 43 (4), pp. 326-338. 
Johnson C. T., Some considerations about sexual abuse and children with sexual behavior problems, in: Trauma and sexuality the effects of childhood sexual, physical, and emotional abuse on sexual identity and behavior, eds. J. Chu, E. S. Bowman, New York 2002.

Kaplow J. B., Widom C. S., Age of onset of child maltreatment predicts long-term mental health outcomes, "Journal of Abnormal Psychology" 2007 No. 116 (1), pp. 176-187.

Knauer S., Recovering from sexual abuse, addictions, and compulsive behaviors: "numb" survivors, New York 2002.

Kaufman J., Zigler E., Do abused children become abusive parents?, "American Journal of Orthopsychiatry" 1987 No. 57, pp. 186-191.

Maltz W., Holman B., Incest and sexuality: a guide to understanding and healing, San Francisco 1987.

Meston C. M., Heiman J. R., The relation between early abuse and adult sexuality, "Journal of Sex Research" 1999 No. 36 (4), pp. 385-395.

Repič T., Spolna zloraba in proces relacijske družinske terapije [unpublished doctoral dissertation, the Faculty of Theology, the University of Ljubljana], Ljubljana 2007.

Repič T., Nemi kriki spolne zlorabe in novo upanje, Celje 2008.

Rothschild B., The body remembers: the psychophysiology of trauma and trauma treatment, New York 2000. 